\title{
First Record of Crinoid Symbiotic Crab, Harrovia japonica (Decapoda: Brachyura: Pilumnidae) from Korea
}

\author{
Seok Hyun Lee and Hyun Sook Ko* \\ Department of Biology, Silla University, Busan 617-736, Korea
}

\begin{abstract}
The crinoid symbiotic crabs, Harrovia japonica were collected for the first time from Geomundo Island in Korea. At present, there are two species of the Eumedoninae in Korean waters.
\end{abstract}

Key words: first record, Harrovia japonica, Pilumnidae, Eumedoninae, Korea

\section{INTRODUCTION}

Eumedoninid crabs of the family Pilumnidae are a specialized group of brachyurans, which are symbiotic with echinoderms. They are easily overlooked due to their small size and cryptic coloration (Castro, 1989). Currently 32 described of 12 genera are known in the Eumedoninae ( $\mathrm{Ng}$ et al., 2008). The genus Harrovia is a obligate symbiont of crinoids and contains seven described species. Harrovia elegans De Man, 1887 has been only known species from Korea (Kim, 1973; Kim and Kim, 1997). H. japonica Balss, 1921 were collected in about $20 \mathrm{~m}$ depth by SCUBA diving. Now, we report firstly this species in the present paper.

Drawings were made with the aid of camera lucida. The abbreviation "cl" refers to carapace length from the tip of the frontal margin to the posterior dorsal margin of the carapace. All specimens were preserved in $95 \%$ ethanol. The classification follows that of $\mathrm{Ng}$ et al. (2008). Materials examined in this study are deposited in collection of Silla University, Busan.

\section{SYSTEMATIC ACCOUNTS}

Superfamily Pilumnoidea Samouelle, 1819

Family Pilumnidae Samouelle, 1819

Subfamily Eumedoninae Dana, 1852

Genus Harrovia Adams and White, 1849

$1 *$ Harrovia japonica Balss, 1921 (Figs. 1, 2)

Harrovia japonica Balss, 1921, p. 177; 1922, p. 136, figs. 8,

9; Chia et al., 1993, p. 266 [note only]; Minemizu, 2000, p. 224; Sakai, 2004, p. 877.

\footnotetext{
*To whom correspondence should be addressed Tel: 82-51-999-9473, Fax: 82-51-999-5176 E-mail: hsko@silla.ac.kr
}

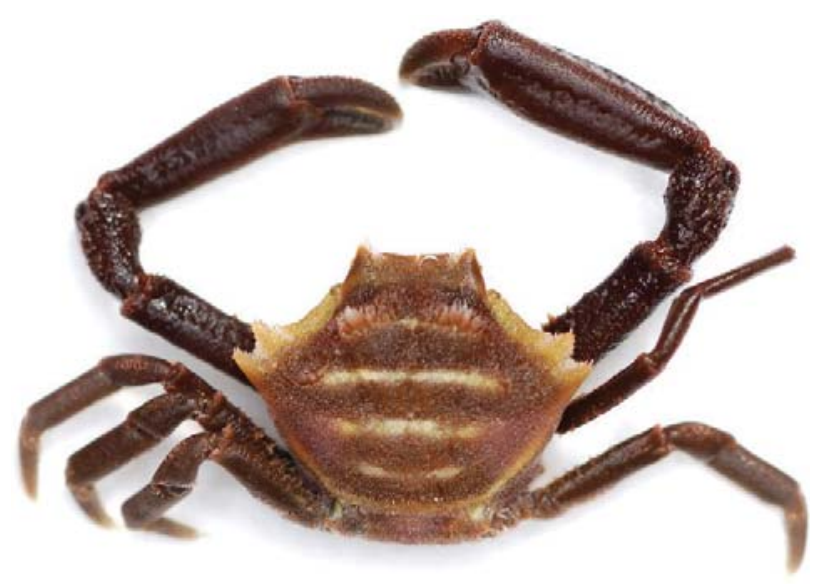

Fig. 1. Harrovia japonica Balss, 1921, male (cl $8.1 \mathrm{~mm}$ ).

Harrovia elegans: Sakai, 1932, pp. 42, 54, pl. 2, fig. 2; 1976, pp. 298-299, fig. 166d, pl. 100; Takeda, 1982, p. 137, fig. 404; Miyake, 1983, pp. 56, 212, fig. 5, pl. 19.

Material examined. 2 이 (cl 7.9, $8.1 \mathrm{~mm}), 1$ 우 (cl $13.9 \mathrm{~mm})$, Geomundo Island, 02 Aug. 2007(S.H. Lee), by SCUBA diving in $20 \mathrm{~m}$ depth, (SUZCR 103259).

Description. Carapace (Figs. 1, 2A, B) hexagonal, 1.4 times broader than long, regions not defined; dorsal surface covered with thick pubescent; protogastric and mesobranchial regions slightly tuberculate, each region with bundle of robust setae. Anterolateral margins separated into 4 lobes; first and second lobes separated by narrow fissure, seemed to be fused, margins granulated and subtruncated, edge of second lobe highly spiniform; third and fourth lobes subequal, highly spiniform, directed anteriorly. Frontal margin with small narrow median fissure, slightly deflexed, almost straight in dorsal view, covered with many tubercles. Infraorbital and

$1 *$ 깃갯고사리게 (신칭) 

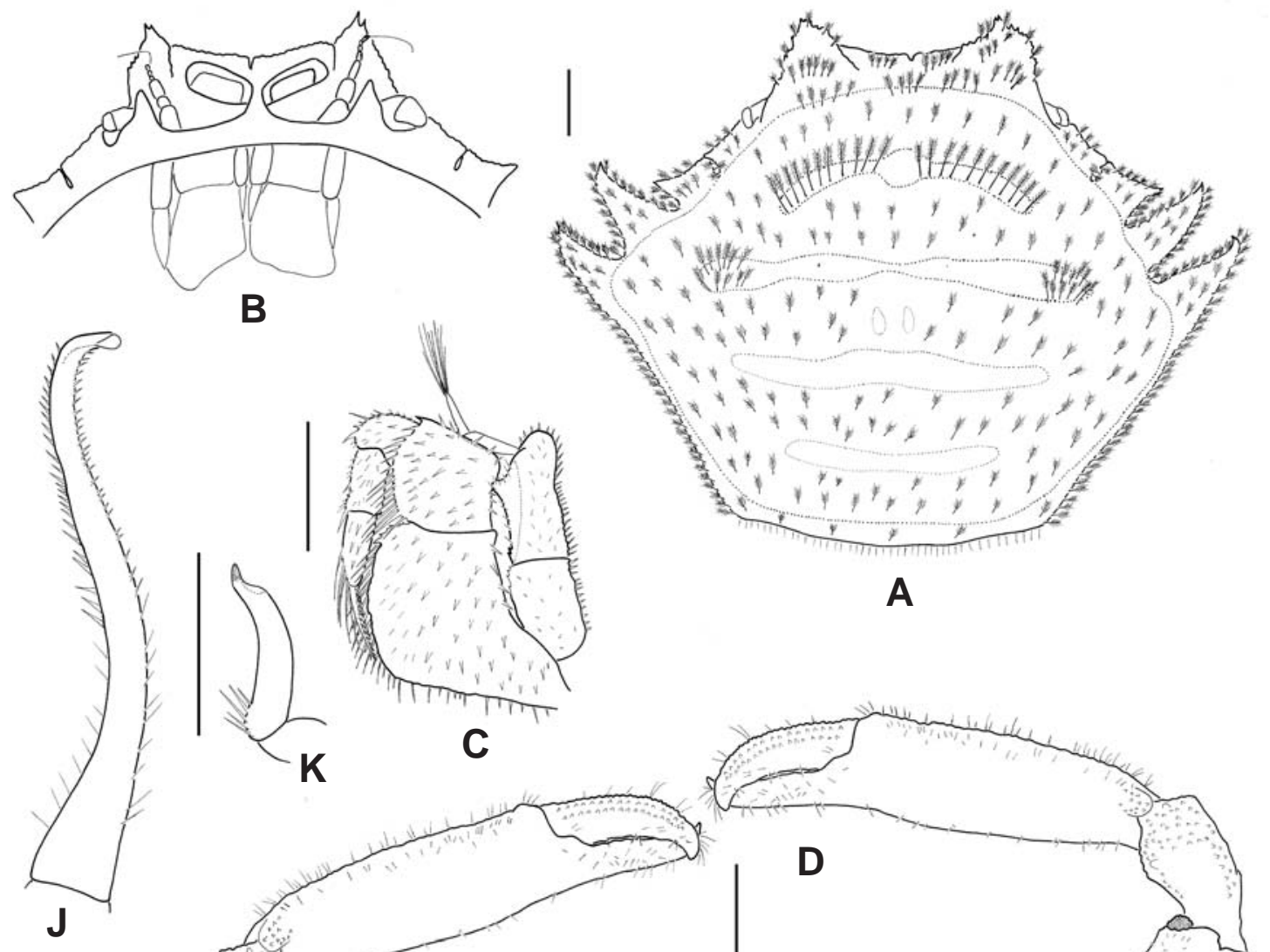

B
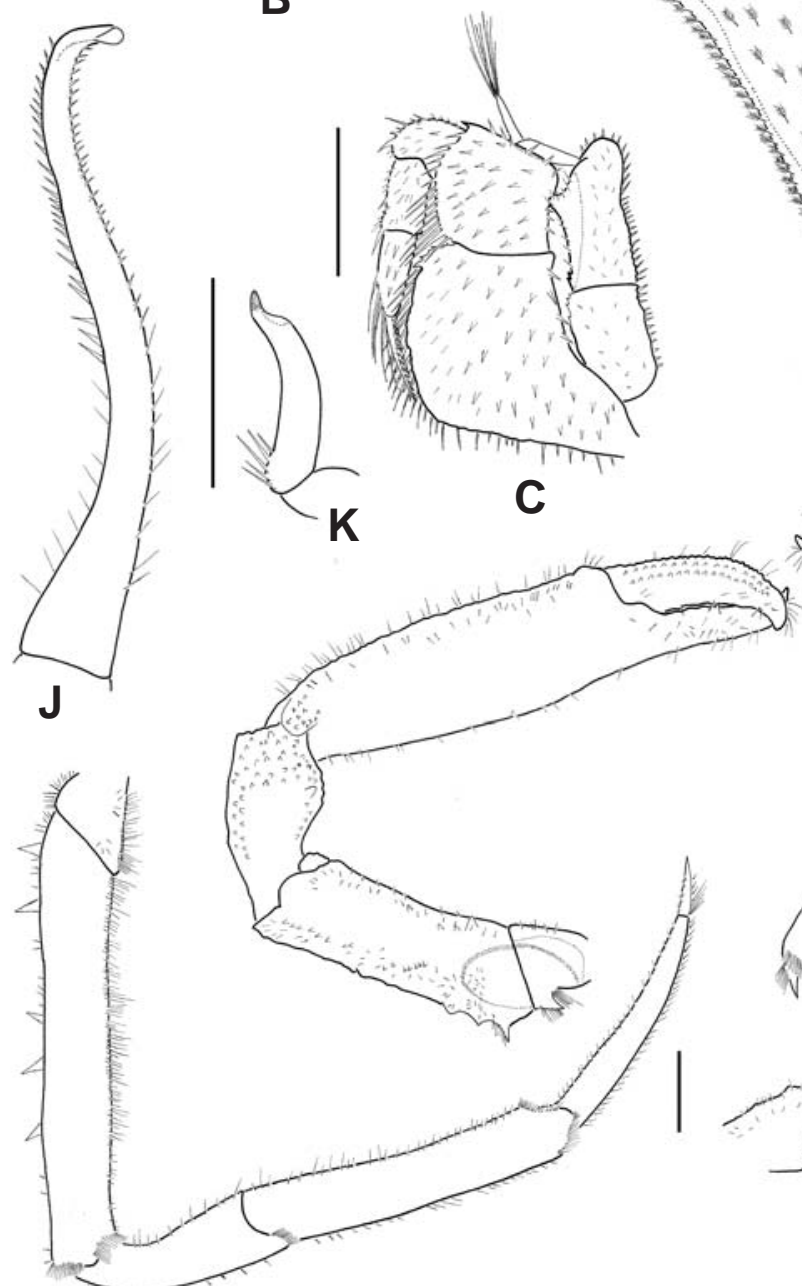
subhepatic teeth comparatively broad and strong.

Third maxilliped (Fig. 2B, C) covered with small setae; ischium subrectangular, small spines on outer margin; bearing setae on inner margin.

Chelipeds (Fig. 2D) long, robust, subcylindrical, subequal; merus with small blunted granules on inner and outer margins, proximal part of merus with 1 or 2 pointed granules on outer margin; carpus with small blunted granules on distal part; propodus covered with setae on outer surface; fingers blunted, recurved, granulated, cutting margins with 2 molarliform teeth.

Ambulatory legs (Fig. 2E-H) generally short, stout, but first ambulatory leg long, slender; merus with 7-8 strong pointed spines on inner margin; carpus and propodus corvered with short and long setae; dactylus pointed, inner and outer margins with short and long setae.

Abdomen of male (Fig. 2I) 7-segmented; telson semicircular, surface smooth.

Gonopods (Fig. 2J, K). First gonopod long, slender, inner and outer margins with setae; tip bent at approximately $90^{\circ}$. Second gonopod short, stout, curved and segmented at proximal part; distal part directed upward.

Color in life. Generally dark reddish brown, with 4 yellowcolored transverse bands on dorsal surface of carapace. Outer margin of carapace except frontal margin yellow.

Habitat. The present specimens were found with crinoids in about $20 \mathrm{~m}$ depth.

Remarks. Although Harrovia japonica was first described by Balss (1921), later it was synonymized with under the name of Harrovia elegans De Man, 1887, by Sakai (1932). Recently, Chia et al. (1993) suggested that $H$. japonica should be regarded as a distinct taxon from $H$. elegans. These two species much resemble each other. However, there are consistent differences in the characters of their anterolateral lobes of carapace. In H. japonica, the first and second anterolateral lobes are separated by a narrow fissure, sometimes seemed to be fused and their edges are highly spiniform and directed anteriorly, but in H. elegans, the former is separated by a wide cleft and the latter is blunted and directed laterally (Chia and Ng, 1998).

Korean specimens agree with $H$. japonica in almost all diagnostic characters proposed by Chia and $\mathrm{Ng}$ (1998), however, some differences are found. The inner and outer margins of first gonopod are with numerous setae and the outer margin of second gonopod is with five proximal setae in the present specimens, while in Chia and $\mathrm{Ng}$ (1998) only the disital part of outer margin of first gonopod is with setae and the outer margin of second gonopod is with seven proximal setae. Such differences seem to be due to intraspecific or geographical variation and may be insignificant.

Distribution. Japan, southern China (Chia and Ng, 1998) and now Korea.

\section{ACKNOWLEDGEMENTS}

We are grateful to Mrs Se Jin Ok for help with drawing.

\section{REFERENCES}

Adams, A. and A. White, 1848, 1849. Crustacea. In Adams, A., ed., The Zoology of the Voyage of H. M. S. Samarang, iviii, 1-66, pls. 1-13. Reeve, Benham, and Reevem London.

Balss, H., 1921. Diagonosen neuer Decapoden aus den Sammlungen der Deutschen Tiefsee-Expedition und der Japanischen Ausbeute Dofleins und Haberers. Zool. Anz., 52: 175178.

Balss, H., 1922. Die Dromiaceen, Oxystomen und Parthenopiden. Ostasiatische Decapoden, III. Arch. Naturgesch, 88: 104-140.

Castro, P., 1989. Range extensions and new host records of eumedonid crabs of the genus Harrovia Adams \& White, 1848 (Decapoda, Brachyura, Eumedonidae). Crustacena, 57(1): 97-100.

Chia, D.G.B. and P.K.L. Ng, 1998. A revision of Ceratocarcinus White, 1847 and Harrovia Adams and White, 1849 (Crustacea: Decapoda: Brachyura: Eumedonidae), two genera of crabs symbiotic with crinoids. Raff. Bull. Zool., 46: 493-563.

Chia, D.G.B., P.K.L. Ng and D. Vandenspiegel, 1993. The identities of two crinoid symbionts, Harrovia albolineata Adams and White, 1849, and H. longipes Lanchester, 1990 (Decapoda, Brachyura, Eumedonidae). Crustaceana, 64(3): 259280.

De Man, J.G., 1887. Report on the Podophthalmous Crustacea of the Mergui Archipelago, collected for the trustees of the Indian Museum. J. Linn. Soc. London (Zoology), 22: 1-312.

Kim, H.S., 1973. Anomura and Brachyura. Illustrated Encyclopedia of Fauna and Flora of Korea, vol. 14. Samwha Publishing Co., Seoul, pp. 1-506.

Kim, H.S. and W. Kim, 1997. Decapoda. In List of Animals in Korea (excluding Insects). Academy Publishing Co., Seoul, pp. 212-223.

Minemizu, R., 2000. Marine Decapod and Stomatopod Crustaceans mainly from Japan. Buninchi Sogo Publ., Co., Ltd., Tokyo, pp. 1-344. (In Japanese)

Miyake, S., 1983. Brachyura (Crabs). Japanese Crustacean Decapods and Stomatopods in Colour. vol. II. Hoikusha Publishing Co. Ltd., Osaka, pp. 1-277.

Ng, P.K.L., D. Guinot and P.J.F. Davie, 2008. Systema Brachyurorum : Part 1. An annotated checklist of extant brachyuran crabs of the world. Raff. Bull. Zool., 17: 1-286.

Sakai, K., 2004. Crabs of Japan. World Biodiversity Database CD-ROM series. 
Sakai, T., 1932. Notes on some rare materials of Japanese Oxyrhyncha. Sci. Rep. Tokyo Bunrika Daigaku, Section B, 1: 41-59.

Sakai, T., 1976. Crabs of Japan and the Adjacent Seas. Kodansha Ltd., pp. 1-773.
Takeda, M., 1982. Keys to the Japanese and foreign Crustaceans. Hokuryukan Ltd., Tokyo, pp. 1-284.

Received January 19, 2009 Accepted February 23, 2009 